\title{
Bioacumulation of Cyanotoxins in Hypophthalmichthys molitrix (Silver Carp) in Paranoá Lake, Brasilia-DF, Brazil
}

\author{
N. B. Oliveira $\cdot$ C. A. Schwartz $\cdot$ C. Bloch Jr. \\ L. Paulino - O. R. Pires Jr.
}

Received: 5 August 2010/Accepted: 26 October 2012/Published online: 22 November 2012

(C) Springer Science+Business Media New York 2012

\begin{abstract}
Three individuals of silver carp (Hypophthalmichthys molitrix) were collected biweekly from Paranoá Lake (DF, Brazil) for analysis of microcystin (MC) concentrations in their muscle and liver tissue. Analysis by high performance liquid chromatography and mass spectrometry revealed MC masses and fragmentation patterns that were identified as MC-LR $(995.04 \mathrm{~m} / \mathrm{z})$, MC-LA $(909.01 \mathrm{~m} / \mathrm{z})$ and an unknown MC $(987.07 \mathrm{~m} / \mathrm{z})$. Concentrations were calculated as MC-LR equivalents using a calibration curve prepared with a standard of MC-LR. May/06 was the month with the highest MC-LR equivalent concentrations in muscle and liver $(3.83 \pm 2.78$, and $12.94 \pm 10.51 \mu \mathrm{g} \mathrm{g}^{-1}$, respectively). Our results show that during the drought months (April-September), consumption of fish with these MC concentrations would result in exposure to MCs that greatly exceed the World Health Organization's recommended tolerable daily intake limit of $0.04 \mu \mathrm{g} \mathrm{MC} \mathrm{kg}{ }^{-1}$ body weight.
\end{abstract}

Keywords Cyanotoxin - Silver Carps ·

Hypophthalmichthys molitrix · Paranoá Lake .

Microcystis · Cyanobacteria

Toxic cyanobacterial blooms in water bodies, with the occurrence of cyanotoxins, are an emerging concern to

N. B. Oliveira · C. A. Schwartz · O. R. Pires Jr. ( $₫)$

Laboratório de Toxinologia, Departamento de Ciências

Fisiológicas, Instituto de Ciências Biológicas,

Universidade de Brasília, Brasília, DF 70910-900, Brazil

e-mail: osmindo@gmail.com

C. Bloch Jr. · L. Paulino

Laboratório de Espectrometria de Massa, Embrapa-cenargen,

Caixa Postal 02372, Brasília, DF, Brazil public health authorities. Human health problems are most likely related with chronic exposure to low microcystin (MC) concentrations through consumption of contaminated water and food. Microcystins are hepatotoxins that also affect organs such as the kidneys and colon (Nobre et al. 1999; Dias et al. 2009; Zegura et al. 2008).

Human poisoning by the consumption of cyanotoxincontaminated water has been reported to have occurred in Australia, England, China and South Africa (Falconer et al. 1994). However, the most serious incident of poisoning by MCs occurred in the city of Caruaru, Brazil, in 1996. During renal dialysis treatment, 116 of 131 patients experienced visual disturbances, nausea, vomiting, and muscle weakness. One hundred patients developed acute liver failure, and 52 eventually died (Jochimsen et al. 1998; Carmichael et al. 2001; Azevedo et al. 2002).

The long-term ingestion of MCs through their bioaccumulation in the aquatic food web also needs to be considered as a means of human exposure to cyanotoxins. Studies with aquatic organisms, including mollusks, turtles, and fish such as carp, trout, goldfish and tilapia have shown cyanotoxin bioaccumulation (Fischer and Dietrich 2000; Xie et al. 2005; Tencalla et al. 1994; Mohamed et al. 2003).

Many studies have reported the bioaccumulation of cyanotoxins in aquatic animals under laboratory conditions (Råbergh et al. 1991; Kotak et al. 1996; Mohamed et al. 2003; Li et al. 2005; Cazenave et al. 2005; Ferreira et al. 2010). However, only a few studies have been conducted in the field (Chen and Xie 2005; Xie et al. 2005; Peng et al. 2010). Thus, the main purpose of this study was to examine the seasonal dynamics of MC bioaccumulation in the tissues of silver carp Hypophthalmichthys molitrix, a phytoplanktivorous species that was introduced into Paranoá Lake, an artificial reservoir with a history of cyanobacteria blooms (Fonseca 2001). 


\section{Materials and Methods}

Three individuals (about $20 \mathrm{~cm}$ ) of silver carp (H. molitrix) were collected biweekly during May/2006 to May/2007 near the South sewage treatment plant in Riacho Fundo creek of Paranoá Lake, Brasília, Brazil. The animals were euthanized with an intraperitoneal injection of $5 \%$ lidocaine. All procedures were in accordance with the Local Ethics Committee.

Tissue samples were collected ( $\sim 5 \mathrm{~g}$ for liver and $10 \mathrm{~g}$ for muscle), homogenized, and extracted three times in methanol $\left(5 \mathrm{~mL} \mathrm{~g}^{-1}\right)$. The extracts were filtered through a glass fiber membrane (1.2 $\mu \mathrm{m}$ porosity), vacuum-dried, and resuspended in deionized water. Aqueous extract cleanup was performed with solid phase extraction cartridges (Strata C18, 5 mg; Phenomenex, Torrance, CA, USA) (Dai et al. 2008). The resultant extract was vacuum-dried and resuspended in $2 \mathrm{~mL}$ of deionized water.

The extracted sample was then filtered through a $0.22 \mu$ polyethylene filter (GV Millex; Millipore Corporation, Billerica, MA, USA), and analyzed with a Shimadzu LC-10A high performance liquid chromatography (HPLC) system (Shimadzu, Kyoto, Japan) equipped with a SPD MXA-10 photodiode array detector. Separations were performed using a Synergi column $(4 \mu \mathrm{m}$ Fusion-RP80, $150 \times 4.60 \mathrm{~mm}$, Phenomenex, Torrance, CA, USA). The mobile phase was $20 \mathrm{mM}$ ammonium formate in $30 \%$ acetonitrile ( $\mathrm{pH}$ 5.0), run isocratically at a rate of $1 \mathrm{~mL} \min ^{-1}$ for $30 \mathrm{~min}$. UV detection was performed at $238 \mathrm{~nm}$. Toxin identification was performed by comparison of chromatograms with a standard of MC-LR (Sigma-Aldrich Corporation, Saint Louis, MO, USA), observing the following aspects: the retention time in chromatography system and similarity of UV spectrograms in the wavelength range of $200-300 \mathrm{~nm}$.
Concentrations of total MCs as MC-LR equivalents were calculated from the calibration curve for the standard of MC-LR. The MC-related HPLC fractions were collected for further identification in the mass spectrometry system (MALDI-TOF/TOF).

Cyanotoxin molecular masses were determined in a matrix-assisted laser desorption/ionization (MALDI-TOF) mass spectrometry system Ultraflex II $^{\mathrm{TM}}$ (Bruker Daltonics, Bremen, Germany). Aliquots of lyophilized toxins were dissolved in deionized water (trifluoroacetic acid(TFA) $0.1 \%$ ) and mixed with a saturated matrix solution of $\alpha$-cyano-4hydroxycinnamic acid $(1: 3, \mathrm{v} / \mathrm{v})$ and directly applied onto a target (AnchorChip ${ }^{\mathrm{TM}}$, Bruker Daltonics, Bremen, Germany). The mass spectrometer was operated in the reflector mode for MALDI-TOF or LIFT mode for MALDI-TOF/TOF using the FlexControl ${ }^{\mathrm{TM}}$ software (Bruker Daltonics, Bremen, Germany).

Water temperature and concentrations of phytoplankton, phosphorus and chlorophyll during the sampling period were provided by the Federal District Environmental Sanitation Company, DF, Brazil. The relationships of these parameters to the concentrations of MCs were evaluated by simple correlation analysis using the statistical software Origin 8.0 (OriginLab Corporation, Northampton, USA).

\section{Results and Discussion}

The HPLC analyses showed three fractions with retention times of 7,11 and $25 \mathrm{~min}$ (Fig. 1), and a spectrogram (range of 200-300 nm) similar to the MC-LR standard with similarity up to $95 \%$ (Fig. 2). These three chromatographic fractions were collected and analyzed by MALDI-TOF/TOF
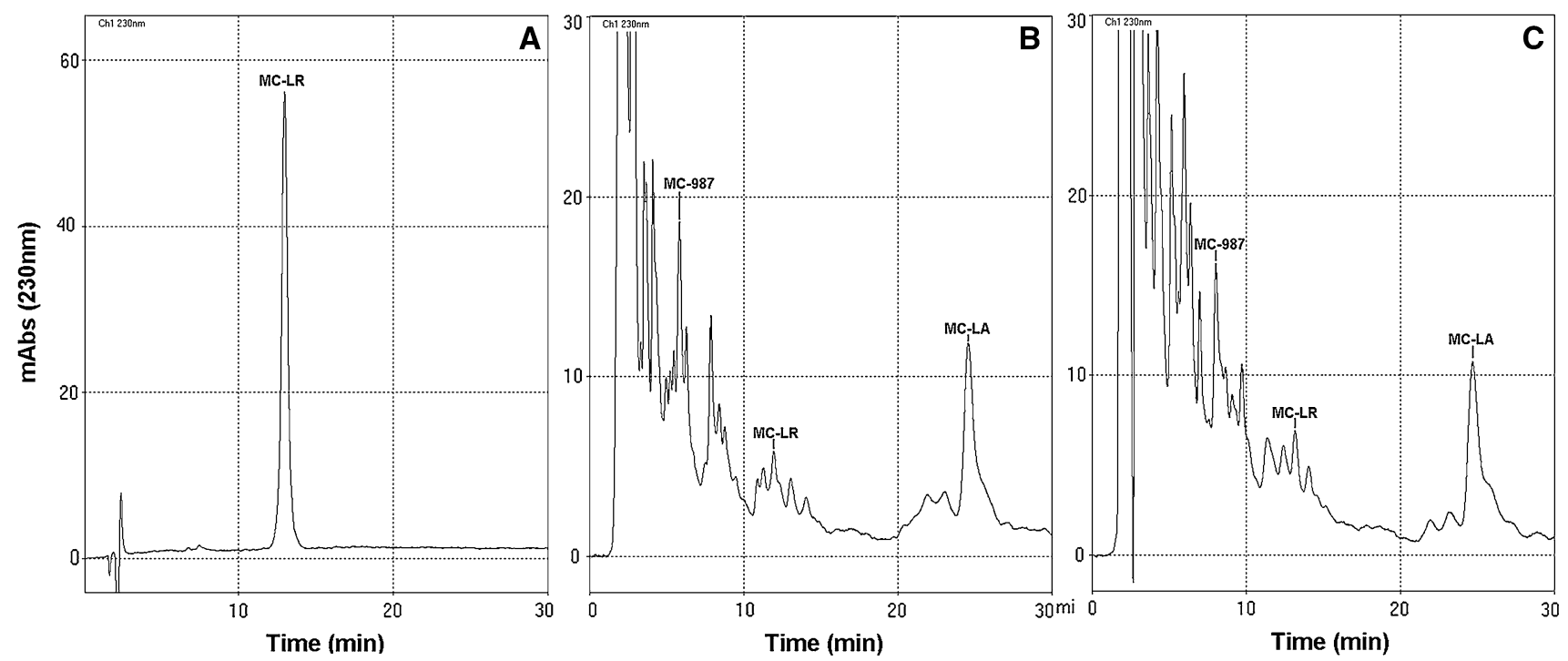

Fig. 1 Chromatogram profile of a liver and b muscle extracts from silver carp H. molitrix collected in Paranoá Lake—Brasília, Brazil 

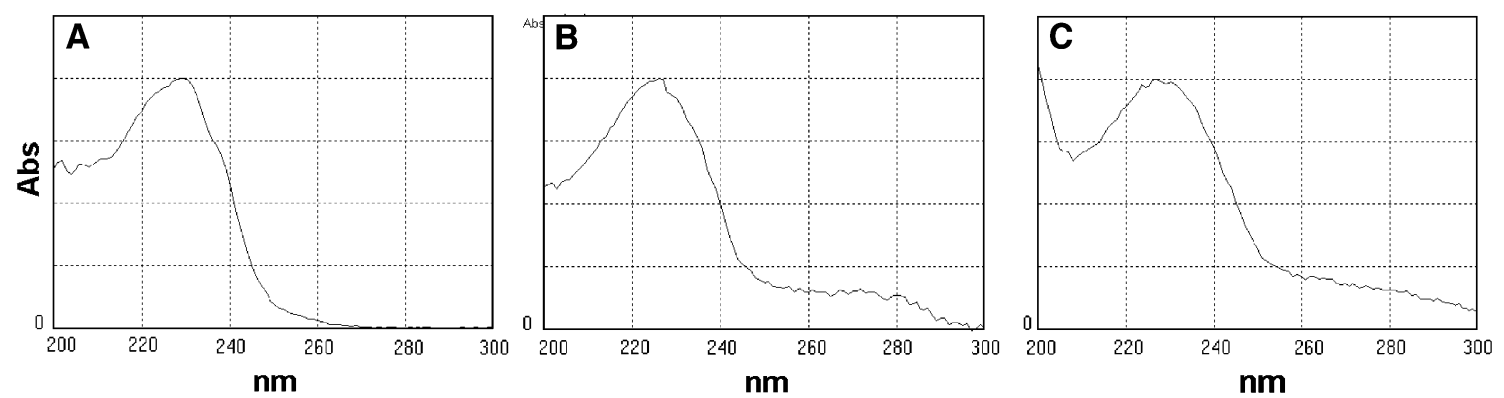

Fig. 2 UV Spectrogram profile range 200-300 of a MC-LR (Sigma), and the chromatographic fractions denoted b MC-987 c MC-LR and d MC-LA

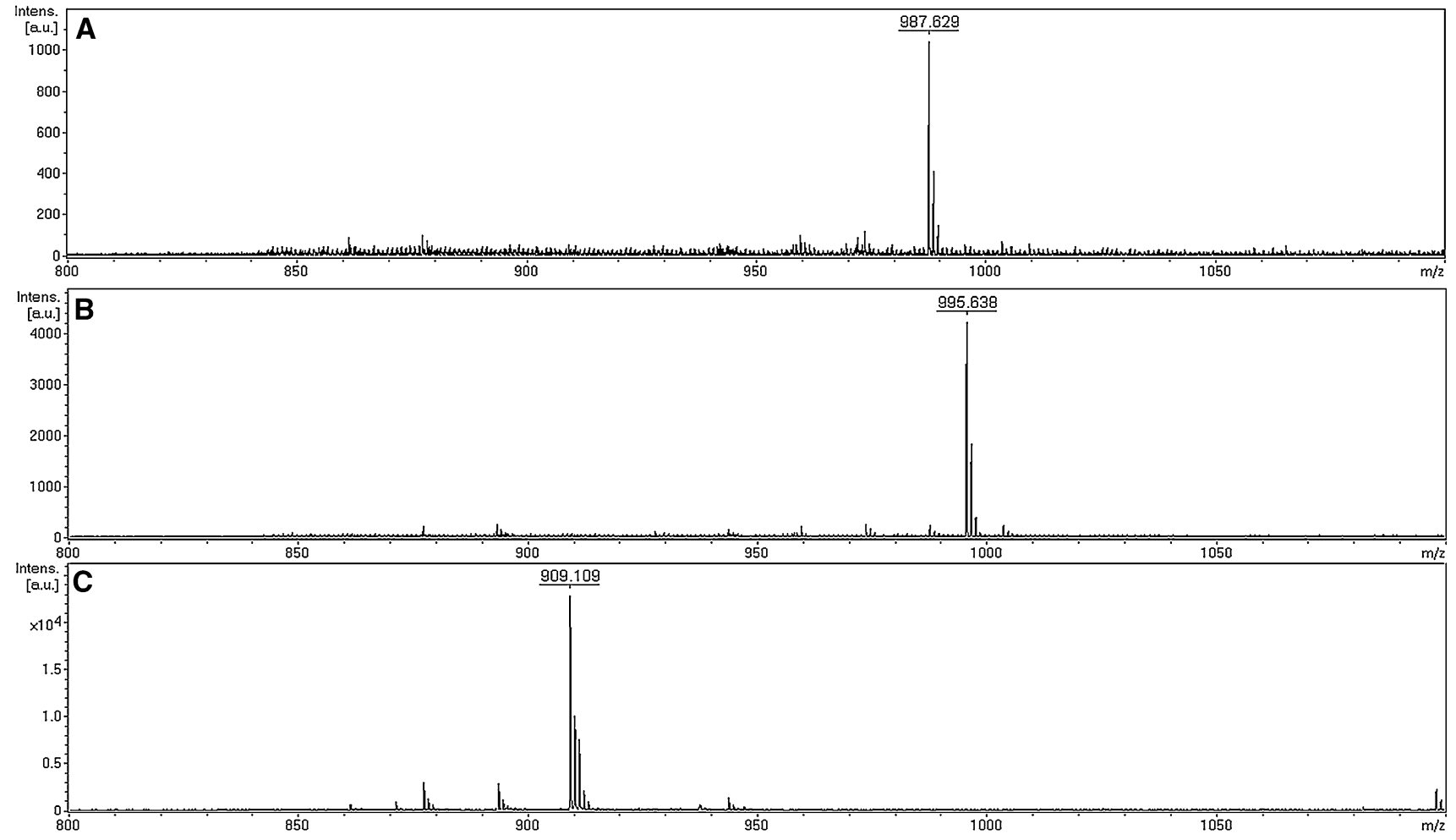

Fig. 3 Mass Spectrogram profile of the chromatographic fractions denoted b MC-987 c MC-LR and d MC-LA, respectively

mass spectrometry, showing mass components at 987.629 , 995.638, and $909.109 \mathrm{~m} / \mathrm{z}$. This suggested the presence of an unknown MC, denoted for this article as MC-987, together with the known MCs, MC-LR and MC-LA, at 995.638 and $909.109 \mathrm{~m} / \mathrm{z}$, respectively (Fig. 3).

All MS/MS fragmentation patterns of the MC-related HPLC fractions showed the presence of ion specific ADDA fragments of $135 \mathrm{~m} / \mathrm{z}$ that confirmed their identities as MC toxins. This also confirmed the presence of MC-LR and MC-LA (Fig. 4).

May/06 was the month with the highest MC-LR equivalent concentration found in muscle and liver (3.8 \pm 2.78, and $12.94 \pm 10.51 \mu^{g_{g}} \mathrm{~g}^{-1}$, respectively) (Fig. 5). Analyzed separately, the concentration of MC-LR in muscle was the highest in June/06.
The World Health Organization (WHO) recommends a tolerable daily intake (TDI) rate of $0.04 \mu \mathrm{g} \mathrm{MC-LR} \mathrm{kg}$ bodyweight (Chorus and Bartram 1999). If a person of $80 \mathrm{~kg}$ body weight consumed a $200 \mathrm{~g}$ fish meal containing $3.8 \mu \mathrm{g} \mathrm{g}^{-1}$ of MC-LR, he/she would have ingested $760 \mu \mathrm{g}$ of this toxin. This would be equivalent to $9.5 \mu \mathrm{g} \mathrm{MC} \mathrm{kg}^{-1}$ bodyweight,which is about 240 times greater than the WHO-recommended TDI.

Thus, the Paranoá Lake silver carp tissue concentrations of MCs during dry periods are well above the WHO recommendations. Magalhães et al. (2001, 2003) monitored fish for MC bioaccumulation in Rio de Janeiro, Brazil. They found that Tilapia rendalli, a widely used exotic species collected in Jaguarepaguá Lagoon also accumulated more MCs than the WHO-recommended TDI. From 


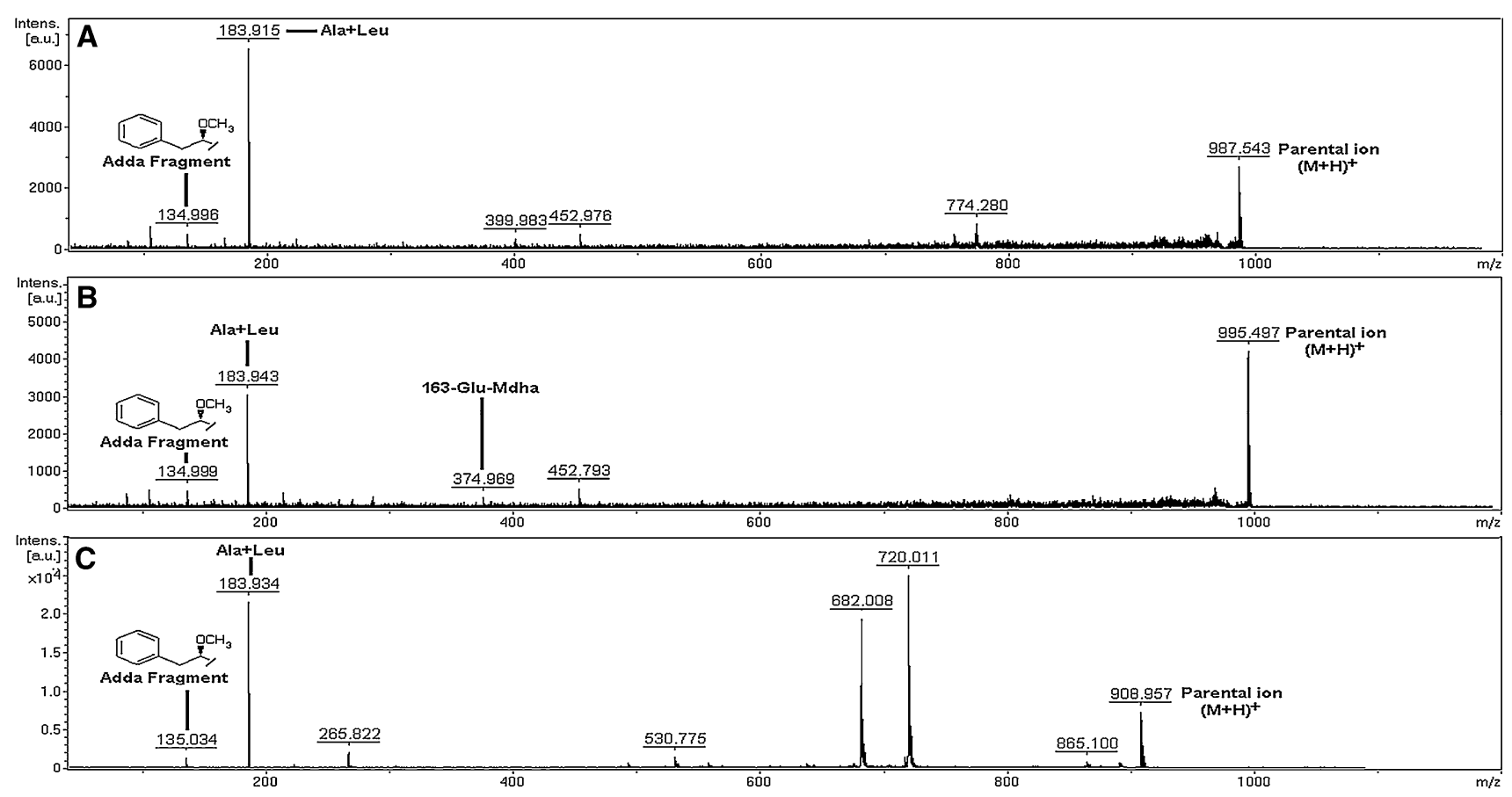

Fig. 4 Mass fragmentation pattern spectrogram of mass components a 987.62 , b 995.63 and $\mathbf{c} 909.10 \mathrm{~m} / \mathrm{z}$ showing the presence of the $135 \mathrm{~m} / \mathrm{z}$ ion confirming their identities as microcystin toxins
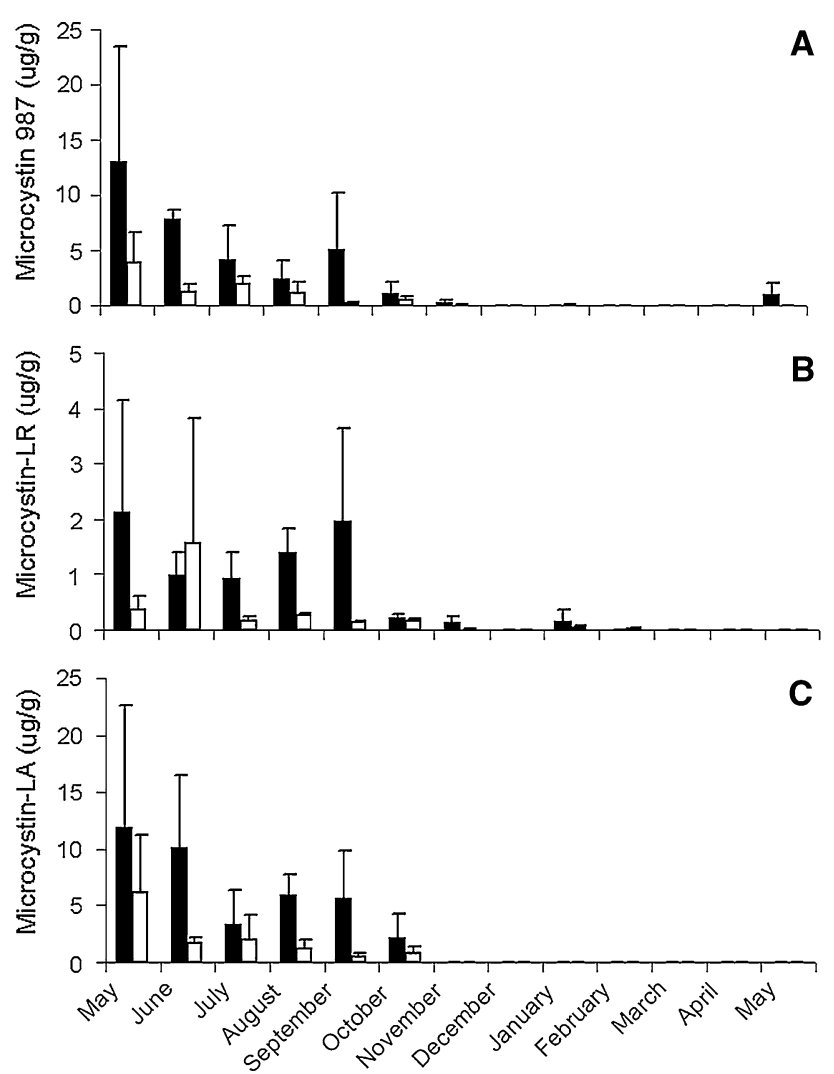

(2006/2007)

Fig. 5 Means and standard deviations of a MC-987 b MC-LR and c MC-LA concentrations over sampling period of May/2006 to May/ 2007. Black and white bars are liver and muscle means, respectively
1997 to March, 1998, the MC concentrations varied from 0 to a high of $980.0 \mu \mathrm{g} \mathrm{g}^{-1}$ (Magalhães et al. 2001). Nineteen percent of various fish and crustacean species collected in 1999 from Sepetiba Bay exceeded the WHOrecommended TDI for MCs (Magalhães et al. 2003).

Several studies have shown the accumulation of MCs in fish tissue. Soares et al. (2004) in a laboratory study complementing the field study of Magalhães et al. (2001), simulated the diet of $T$. rendalli during a Microcystis aeruginosa bloom. They observed that $T$. rendalli accumulated MCs. Mohamed et al. (2003) found MCs in liver, kidney, gut and muscle of Oreochromis niloticus in an Egyptian fish farm. Cazenave et al. (2005) detected MC in liver, gill, muscle and brain of Odontesthes bonariensis collected from a reservoir of Argentina on two sampling dates. Xie et al. (2005) measured MCs in gut, liver, kidney, muscle, blood and bile of eight species of fish in Lake Chaohu of China.

No significant relationships were observed between the temperature, phosphorus, phytoplankton or chlorophyll concentrations (Fig. 6) versus MCs concentrations during the execution of this work, as all correlation coefficients $\left(\mathrm{R}^{2}\right)$ were less than under 0.10 . According to the Brazilian National Institute of Meteorology data (INMET 2007) an intense drought began in May, 2006, and ended in September, 2006. Interestingly, with the onset of precipitation following the drought, a decline occurred in the concentrations of MC-LR equivalents in fish tissue. This suggests 

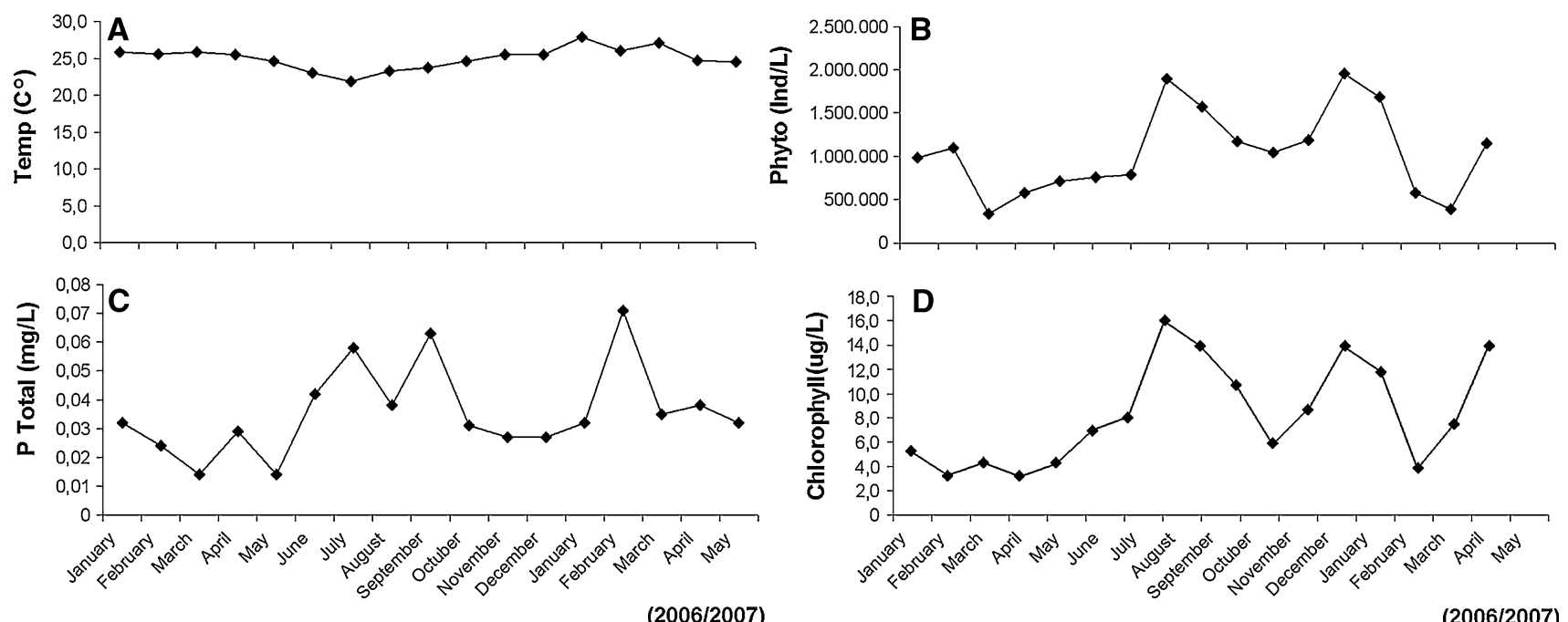

$(2006 / 2007)$

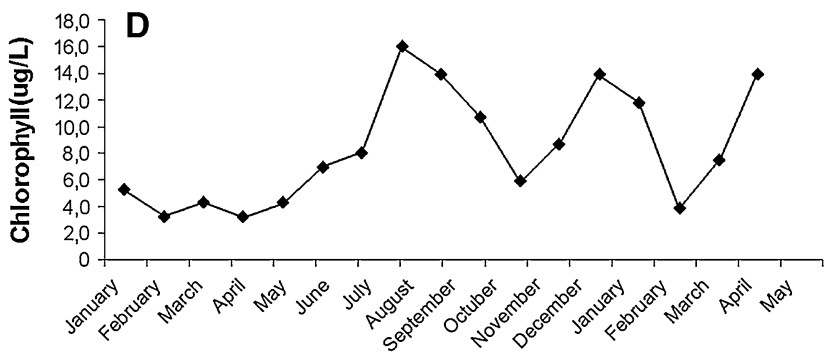

(2006/2007)

Fig. 6 a Temperature and concentration of $\mathbf{b}$ phytoplankton, $\mathbf{c}$ phosphorus and $\mathbf{d}$ chlorophyll in Paranoá Lake during the sampling period of May/2006 to May/2007

that the abundance of toxic cyanobacteria and the concentrations of MCs may be related to precipitation.

Brasília was constructed to be Brazil's federal capital. In its urban plan, a barrier was built on the Paranoá River to form a lake that would frame the city. Unfortunately, the population increased in disaccord with the sewer and water treatment capacity. For years, Paranoá Lake has received urban sewage without significant treatment, causing eutrophication of the lake. The Federal District Environmental Sanitation Company (CAESB) attempted to reverse this situation by adopting an urgent and long-term solution. In spite of this effort, Philomeno (2003) showed that M. aeruginosa and Cylindrospermopsis raciboskii still appear as the major algae in the phytoplankton community of Paranoá Lake during different seasons, and their abundances increased significantly during the normally dry winter season. In 2004, Pires Jr. (unpublished data) measured $311 \mu \mathrm{g} \mathrm{g}^{-1}$ of MC-LR in a freeze-dried bloom of M. aeruginosa in Paranoá Lake. In an attempt to reduce the amount of cyanobacteria in Lake Paranoá, silver carp were introduced (Starling 1993).

Unfortunately, the important issue of health risks associated with consumption of fish that have bioaccumulated cyanobacterial toxins remains poorly studied. Potential health risks continue for residents of Brazil who consume fish caught from this and similar lakes, as neither legislation nor long-term study of health risks have been proposed.

In conclusion, our study has shown that concentrations of MCs are above WHO-recommended TDI levels during dry periods. Therefore, we recommend that silver carp from Paranoá Lake should not be consumed during the dry season of winter, or during other periods of drought.
Acknowledgments We thank the CNPq and FINATEC for financial support, and the Federal District Environmental Sanitation Company for kindly providing data on temperature and concentrations of phytoplankton, phosphorus and chlorophyll during the sampling period of May/2006 to May/2007. We especially thank Dr. Fernando Starling and employees, Julianna and Tião, for the supplying the fish for this study.

\section{References}

Azevedo SMFO, Carmichael WW, Jochimsen EM, Rinehart KL, Lau S, Shaw GR, Eaglesham GK (2002) Human intoxication by microcystin during renal dialysis treatment in Caruaru-Brazil. Toxicology 181:441-446

Carmichael WW, Azevedo SMFO, An J, Molica RJR, Jochimsen EM, Lau S, Rinehart KL, Shaw GR, Eaglesham GK (2001) Human fatalities from cyanobacteria: chemical and biological evidence for cyanotoxins. Environ Health Perspect 109:663-668

Cazenave J, Wunderlin DA, Bistoni MA, Am'e MV, Krause E, Pflugmacher S, Wiegand C (2005) Uptake, tissue distribution and accumulation of Microcystin-RR in Corydoras paleatus, Jenynsia multidentata and Odontesthes bonariensis. Aquat Toxicol 75:178-190

Chen J, Xie P (2005) Seasonal dynamics of the hepatotoxic microcystins in various organs of four freshwater bivalves from the large eutrophic Lake Taihu of subtropical China and the risk to human consumption. Environ Toxicol 20:572-584

Chorus I, Bartram J (1999). Toxic cyanobacteria in water : a guide to their public health consequences, monitoring and management. In: Chorus I ,Bartram J. (eds) (E \& FN Spon) Available at: http://www.earthprint.com

Dai M, Xie P, Liang GD, Chen J, Lei HH (2008) Simultaneous determination of Microcystin-LR and its glutathione conjugate in fish tissues by liquid chromatography-tandem mass spectrometry. J Chromatogr B 862:43-50

Dias E, Andrade M, Alverca E, Pereira P, Batoreu MC, Jordan P, Silva MJ (2009) Comparative study of the cytotoxic effect of microcystin-LR and purified extracts from $M$. aeruginosa on a kidney cell line. Toxicon 53:487-495 
Falconer IR, Burch MD, Steffensen DA, Choice M, Coverdale OR (1994) Toxicity of the blue-green algae (cyanobacterium) Microcystis aeruginosa in drinking water to growing pigs, as an animal model for human injury and risk assessment. Environ Toxicol Water Qual 9:131-139

Ferreira MFN, Oliveira VM, Oliveira R, Cunha PV, Grisolia CK, Pires Jr OR (2010) Histopathological effects of [D-Leu1] Microcystin-LR variants on liver, skeletal muscle and intestinal tract of Hypophthalmichthys molitrix (Valenciennes, 1844). Toxicon 55:1255-1262

Fischer WJ, Dietrich DR (2000) Pathological and biochemical characterization of microcystin-induced hepatopancreas and kidney damage in carp (Cyprinus carpio). Toxicol Appl Pharmacol 164: $73-81$

Fonseca FO (2001) Olhares sobre o Lago Paranoá. $1^{\text {a }}$ Edição, Secretaria de Meio Ambiente e Recursos Hídricos, Brasília, DF, Brazil

INMET (2007) http://www.inmet.gov.br/html/observacoes.php?lnk= Capitais. Accessed Aug 2007

Jochimsen EM, Carmichael WW, An JS, Cardo DM, Cookson ST, Holmes CEM, Antunes MBC, Melo-Filho DA, Lyra TM, Barreto VST, Azevedo SMFO, Jarvis WR (1998) Liver failure and death after exposure to microcystins at a haemodialysis center in Brazil. N Engl J Med 33:873-878

Kotak BG, Semalulu S, Fritz DL, Prepas EE, Hrudey SE, Coppock RW (1996) Hepatic and renal pathology of intraperitoneally administered microcystin-LR in rainbow trout (Oncorhynchus mykiss). Toxicon 34:517-525

Li L, Xie P, Chen J (2005) “In vivo" studies on toxin accumulation in liver and ultrastructural changes of hepatocytes of the phytoplanktivorous bighead carp i.p-injected with extracted microcystins. Toxicon 46:533-545

Magalhães VF, Soares RM, Azevedo SMFO (2001) Microcystin contamination in fish from the Jacarepaguá Lagoon (Rio de Janeiro, Brazil): ecological implication and human health risk. Toxicon 39:1077-1085

Magalhães VF, Marinho MM, Domingos P, Oliveira AC, Costa SM, Azevedo LO, Azevedo SMFO (2003) Microcystins (cyanobacteria hepatotoxins) bioaccumulation in fish and crustaceans from Sepetiba bay (Brazil, RJ). Toxicon 42:289-295
Mohamed ZA, Carmichael WW, Hussein AA (2003) Estimation of microcystins in the freshwater fish Oreochromis niluticus in an Egyptian fish farm containing a Microcystis bloom. Environ Toxicol 18:137-141

Nobre ACL, Jorge MCM, Menezes DB, Fonteles MC, Monteiro HSA (1999) Effects of microcystin-LR in isolated perfused rat kidney. Braz J Med Biol Res 32:985-988

Peng L, Liu Y, Chen W, Liu L, Kent M, Song L (2010) Health risks associated with consumption of microcystin-contaminated fish and shellfish in three Chinese lakes: significance for freshwater aquacultures. Ecotoxicol Environ Saf 73:1804-1811

Philomeno MG (2003) A estrutura da comunidade fitoplanctônica em dois períodos sazonais no Lago Paranoá, Brasília-DF. Tese, Universidade de Brasília, Brazil

Råbergh CMI, Bylund G, Erikssonl JE (1991) Histopathological effects of microcystin-LR, a cyclic peptide toxin from the cyanobacterium (blue-green alga) Microcystis aeruginosa, on common carp (Cyprinus carpio L.). Aquat Toxicol 20:131-146

Soares RM, Magalhães VF, Azevedo SMFO (2004) Accumulation and depuration of microcystins (cyanobacteria hepatotoxins) in Tilapia rendalli (Cichlidae) under laboratory conditions. Aquat Toxicol 70:1-10

Starling FLRM (1993) Control of Eutrophication by Silver Carp (Hypophthalmichthys molitrix) in the Tropical Paranoá Reservoir (Brasília, Brazil): a Mesocosm Experiment, Companhia de Agua e Esgotos de Brasília (CAESB). Hydrobiologia 257(3):143-152

Tencalla F, Dietrich D, Schlatter C (1994) Toxicity of Microcystis aeruginosa peptide toxin to yearling rainbow trout (Oncorhynchus mykiss). Aquat Toxicol 30:215-224

Xie L, Xie P, Guo L, Li L, Miyabara Y, Park H (2005) Organ distribution and bioaccumulation of microcystins in freshwater fish at different trophic levels from the eutrophic Lake Chaohu. China Environ Toxicol 20(3):293-300

Zegura B, Volcic M, Lah TT, Filipic M (2008) Different sensitivities of human colon adenocarcinoma (CaCo-2), astrocytoma (IPDDC-A2) and lymphoblastoid (NCNC) cell lines to microcystinLR induced reactive oxygen species and DNA damage. Toxicon $52: 518-525$ 